\title{
The waltz of volatile molecules
}

Christophe Laudamiel

From 1st International Workshop on Odor Spaces

Hannover, Germany. 4-7 September 2013

Abstract not submitted for online publication.

Published: 16 April 2014

doi:10.1186/2044-7248-3-S1-K7

Cite this article as: Laudamiel: The waltz of volatile molecules. Flavour 2014 3(Suppl 1):K7. 